\title{
Predominance of Spirastrella inconstans Protein over Enzymes of Marine Bacteria against MRSA
}

\author{
A. Mohankumar ${ }^{1} \&$ S. Tamil Selvi ${ }^{2}$ \\ ${ }^{1}$ Department of Zoology, Chikkanna Govt. Arts College, Tirupur 641602, Tamilnadu, India \\ ${ }^{2}$ Department of Microbiology, Sengunthar Arts and Science College, Tiruchengode 637205, Tamilnadu, India \\ Correspondence: A. Mohankumar, Department of Zoology, Chikkanna Govt. Arts College, Tirupur 641602, \\ Tamilnadu, India. Tel: 91-984-279-1195. E-mail: moniver@satyam.net.in
}

$\begin{array}{lr}\text { Received: April 19, } 2012 & \text { Accepted: May 7, } 2012 \quad \text { Online Published: June 13, } 2012 \\ \text { doi:10.5539/ijb.v4n3p80 } & \text { URL: http://dx.doi.org/10.5539/ijb.v4n3p80 }\end{array}$

\begin{abstract}
Fisherman community people will have significant value if they used powder form of marine organism for wound healing caused by MRSA. The bioactivity was more prevalent in sponge, Spirastrella inconstans compared to other marine organism. The protein was fractioned by ammonium sulphate precipitation method and purified using dialysis. About $1000 \mu$ of dialysate were loaded on Sephadex G-50 chromatographic column and purified 75 fractions at each percentage of saturation were collected. The fraction no. 3, 4 (40\% saturation) and no. 4 (60\% saturation) bears maximum protein content. Amount of protein content was estimated in UV-Vis Spectrophotometer, preliminary detection of compound was carried out by TLC. Two fractions were efficient and their $R_{f}$ values were found to be similar to that of glutamic acid. The molecular weight of protein was calculated as 3000 Da by SDS-PAGE. Marine bacterial cultures were isolated and enzymes (amylase, DNase, esculinase, lipase, gelatinase and alginase) were produced and lipase bearing maximum activity was treated against MRSA. Compared to other marine organism, sponge protein obtained during our period of study was effective.
\end{abstract}

Keywords: Spirastrella inconstans, marine source, enzyme, protein, lipase, bioactive compound

\section{Introduction}

The marine ecosystem represents $95 \%$ of the biosphere, and all except one of the 33 animal phyla are represented in aquatic environments. Most sessile marine invertebrates contain a primitive immune system and produce toxic chemicals as a form of defense. Many of these products act as regulators of specific biological functions. Some of them have pharmacological activity due to their specific interactions with receptors and enzymes. Because these substances get diluted by seawater, they need to highly potent on a molar basis, and also have to retain a relatively low solubility. The development of marine compounds as therapeutic agents is still in its infancy due to the lack of analogous ethno-medical history as compared with terrestrial habitats, together with the relative technical difficulties in collecting marine organisms (Amador et al., 2003).

Enzymes are biocatalysts which assist numerous highly diverse reactions. They have found applications in various domains including therapeutics. It has been reported that molecules of marine origin may differ in properties from their terrestrial counterparts. Marine microorganisms (epibionts and endo-symbionts), due to the unusual niche in which they are found are also being explored for therapeutically and industrially important molecules. Enzymes from theses symbionts perhaps have characteristics such as heat tolerance, cryo-tolerance, pH tolerance, metal tolerance etc (Tonima et al., 2008).

Sponges possess an efficient chemical defense system to inhibit bacterial growth. Triggered by ecological constraints, Porifera developed a large variety of biologically highly active compounds that were shaped during the last 1 billion years for optimal specificity and activity. Second, sponges are provided with efficient humoral and cellular defense or immune mechanism that share, at the sequence level, surprisingly high similarity with the immune molecules found in humans. Third, a mechanism in these animals eliminates microorganisms by engulfing them through phagocytosis (Schroder et al., 2003).

The rich diversity in bioactive compounds from sponge has provided molecules that interfere with the pathogenesis of a disease at many different points, which increase the chance of developing selective drug 
against specific targets. The secondary metabolites are usually present in trace amounts, and natural stocks are too small to sustain the development of widely available medicines. The current metabolites are to study the feasibility of pharmaceuticals from sponges at a large-scale. A combined approach of genetically modified bacterial fermentation (to produce a precursor molecule) followed by a limited number of chemical steps to produce molecules that are derived from sponge chemicals to develop medicines from sponge metabolites that are present in low concentration (Ravichandran et al., 2007).

Bioprospecting of marine organisms as source of bioactive metabolites that may be directly utilized as drugs or serve as lead structures for drug development started in the late 1960s. Boobathy et al. (2009) reported that in the Gulf of Mannar and Palk Bay a maximum of 275 species of sponges have been recorded. The rapid development of the pharmaceutical market has brought about a bloom of information regarding various toxins native to the sponges. Recently various technologies developed to produce novel products from marine sponges; these could contribute to human healthcare.

Sponges were mostly found in Gulf of Mannar, located on the southeastern tip of India in the state of Tamilnadu. It is the first marine biosphere reserve in all of South and Southeast Asia, extending from Rameswaram Island to Tuticorin in a NE-SW direction to a distance of $140 \mathrm{~km}$ with a width of $25 \mathrm{~km}$. It comprises 21 islands running almost parallel to the coastline between latitude $8^{\circ} 47^{\prime} \mathrm{N}$ and $9^{\circ} 15^{\prime} \mathrm{N}$ and longitude $78^{\circ} 12^{\prime} \mathrm{E}$ and $79^{\circ} 14^{\prime} \mathrm{E}$ with three distinct marine ecosystems namely corals, sea grass and mangroves. Around 3600 species of fauna and flora have been identified including approximately 108 species of sponges (Limna et al., 2010).

The number of natural products isolated from marine organism increases rapidly and now exceeded 18000 by 2007. They can be considered as "microbial fermenters" that hold a largely untapped potential for therapeutics (Microbiologists are highly fascinated by sponges, as they are associated with enormous amounts of microorganisms Satheeshkumar et al., 2010).

The aim of this research was to carry out laboratory studies on the production, purification and characterization of enzyme from marine bacteria (from marine sediment and water) and marine sponge, Spirastrella inconstans against MRSA (Methicillin Resistant Staphylococcus aureus), isolated from fisherman wound. The result of the hypothesis shows that activity of marine bacteria was less efficient, when compared to that of proteins from Spirastrella inconstans, which is initially considered as may or may not have bioactive compound.

\section{Materials and Methods}

\subsection{Isolation of Marine Bacteria from Sediment Sample}

Collected soil sediment (1.0 gm) and marine water samples at east and west coast region in India using clean and sterile container. Pour plating method was followed in marine agar, TCBS and Zobell Marine agar plates. Further microbiological analyses were carried out using biochemical characterization.

\subsection{Isolation of Marine Bacteria from Rat Fish}

Rat fish (Clarias batrachus) was isolated from marine source of Kanyakumari region. Dorso-ventral region of the Clarias batrachus was dissected, to remove the digestive system. The small intestine region was homogenized and the suspension $10^{-1}$ was used for isolation of gut flora. Serial dilution technique (Nagvenkar et al., 2006), followed by pour plating method using tryptic soya agar plates (Tahere et al., 2008).

\subsection{Extracellular Enzyme Production in Marine Bacteria by Plate Precipitation Test}

\subsubsection{Screening of Lipolytic Enzymes}

a. Lipase identification and production: Lipase was screened by using Rhodamine B agar (Anshu et al., 2002) and Sprit blue agar method (Gisela, 1987); production was carried out by inoculating colony in $10 \mathrm{ml}$ olive oil broth and incubated at $37^{\circ} \mathrm{C}$ on a shaker at $240 \mathrm{rpm}$ for $24 \mathrm{hrs} .5 \mathrm{ml}$ of the culture was inoculated in $100 \mathrm{ml}$ of fresh fermentation medium, incubated at $37^{\circ} \mathrm{C}$ for $96 \mathrm{hrs}$ in at $100 \mathrm{rpm}$, centrifuged at $10000 \mathrm{rpm}$ for $30 \mathrm{~min}$ at $4^{\circ} \mathrm{C}$. The supernatant was used as the source of extracellular enzyme.

b. Lipase assay by olive oil substrate emulsion method (Titration method): Assay mixture with $0.1 \mathrm{ml}$ of substrate emulsion, $0.9 \mathrm{ml}$ of $0.2 \mathrm{M}$ Potassium Phosphate buffer $\mathrm{pH} 7.0$ and $0.2 \mathrm{ml}$ of aliquot were incubated at $55^{\circ} \mathrm{C}$ for $30 \mathrm{~min}$. Terminated by adding $2.0 \mathrm{ml}$ of acetone-ethanol mixture. Amount of liberated fatty acid was determined by titration with $0.1 \mathrm{~N} \mathrm{NaOH}$ using $1 \%$ phenolphthalein indicator. 1.0 unit of Lipase activity was defined as the amount of enzyme required to liberate $1 \mathrm{M}$ mole equivalent fatty acid/ml/minute of the enzyme extract. 


$$
\text { Lipase activity }(\text { units } / \mathrm{ml} / \mathrm{min})=\frac{\text { Volume of } \mathrm{NaOH} \times \mathrm{Normality} \text { of } \mathrm{NaOH} \times 7 \times 1000}{\text { Incubation time }(30 \mathrm{~min})}
$$

\subsubsection{Protease Plate Assay}

Proteolytic microorganisms were isolated from gut content on skimmed milk agar, incubated for $72 \mathrm{hrs}$. Protease was detected by appearance of haloes (Nagvenkar et al., 2006).

\subsubsection{Utilization of Fish (Scamberomonas Gattatus) Waste for the Isolation of Protease}

a. Preparation of crude homogenate: Precipitation of protease was done by ammonium sulphate fractionation, using visceral organ waste of fish $S$. gattatus waste. Molecular weight was determined by SDS-PAGE using $10-13 \%$ gradient gel on a continuous buffer system. Assay of Protease was performed calorimetrically using Casein as substrate. Confirmation of Protease by Zymography was carried out using 50\% ammonium sulphate precipitated sample. Protease posses the ability to dissolve blood clot and involved in the treatment of wound infection.

Plating method was followed to identify amylase Nagvenkar et al., 2006), DNase, Gelatinase, Esculinase (Davis \& Ewing, 1964), Alginase production.

Effect of organic solvents on enzymes activity: Methanol, ethanol, acetone, Dimethyl sulphoxide (DMSO), glycerol, polyethylene glycol, hexane, benzene $(10 \%, 30 \% \mathrm{v} / \mathrm{v})$ were added to the reaction mixture and determined by assay conditions. $60 \%$ of hexane or benzene was used for assay in reaction mixture (Neerupama et al., 2006).

Effect of environmental variables on lipase production: Various carbon sources were studied by replacing Tween 80 in production medium with different lipidic and non-lipidic sources. Yeast extract was replaced with various organic and inorganic nitrogen sources. Using $0.5 \%$ Tween 80 , as carbon source, the effect of oleic acid supplementation on lipase production was done. The $p \mathrm{H}$ of the production medium was 5.0-10.0 (Prabhdeep et al., 1998).

Activity analysis of lipase: The SDS-PAGE gels were washed for $20 \mathrm{~min}$ in $2.5 \%$ Triton X-100 in water, 2.5\% Triton X-100 in phosphate-buffered saline (PBS) and pure PBS. Stained with Coomassie brilliant blue for 20 min and washed. $1-5 \%$ tributyrin, $0-1 \%$ gum arabic, and $100 \mu \mathrm{g}$ of Streptomycin per ml were added to melted $\mathrm{L}$ agar. Gels were laid onto solidified surface and second layer was added to embed the gels, opaque agar was observed. Tributyrin was replaced by $1.5 \%$ pure olive oil and bands were studied (Jan \& Staffan, 1992).

Detection of lipase activity by zymography: Proteins were separated on $7.5 \%$ (w/v) SDS-PAGE gels. SDS was removed from gels by sequential washes in $0.1 \%(\mathrm{v} / \mathrm{v})$ Triton X-100 along with water and PBS only for 20 min each. Gels were placed on Nutrient agar plates containing $1 \%(\mathrm{w} / \mathrm{v})$ tributyrin and overlaid with $10 \mathrm{ml}$ molten Tributyrin agar at $40^{\circ} \mathrm{C}$. Plates were incubated at $37^{\circ} \mathrm{C}$ for $24-48 \mathrm{hrs}$ and bands exhibiting lipase activity defined by zones of clearing (Longshaw, 2000).

\subsection{Crude Sponge Aqueous Extraction}

The aqueous extract of sponge was prepared by squeezing the sand free specimens in distilled water. The resultant solution was filtered and dialyzed by using Sigma dialysis membrane 500 against D-glucose. The supernatant was used as crude aqueous extract.

\subsubsection{Solvent Extraction}

The sponge sample was collected from Gulf of Mannar, India and identified by the scientist of Zoological Survey of India (ZSI), Chennai, Tamilnadu, India. They were stored at $-20^{\circ} \mathrm{C}$ and transporte below $0{ }^{\circ} \mathrm{C}$ and identified as Spirastrella inconstans. $10 \mathrm{gm}$ of Spirastrella inconstans tissue was soaked with $200 \mathrm{ml}$ of solvents, covered and kept standing for 5 hrs. The solvent was then removed after squeezing the sponge and filtered through Whatman No 1 filter paper then evaporated at $45^{\circ} \mathrm{C}$ according to the method of Gerald and Green Gerardo (1981).

Homogenized Spirastrella inconstans (20 gm) was taken with different solvents such as Chloroform, dichloromethane, methanol, ethanol, petroleum ether and acetone. They were soaked, packed tightly and kept in dark condition for three days, though the biomolecules present in Spirastrella inconstans get mixed with solvent. The process was repeated using fresh solvent, until it is quite satisfy that the entire bioactive compound gets dissolved in solvent, has been extracted. The supernatant, which is yellowish when extracted for the first time, indicated the presence of solvent-soluble compounds while the supernatant, which is crystal clear when extracted for the third time, indicated that there are no more solvent-soluble compounds present in it (Zakaria et al., 2004). 
The solvent was evaporated to form layer. One $\mathrm{ml}$ of solvent is poured over the precipitate and the extract was used for antimicrobial activity against MRSA strains isolated from fisherman community.

\subsubsection{Characterization of Protein}

The presence of protein was quantitatively estimated by Lowry's method (Lowry et al., 1951). Ammonium sulphate precipitation method was adopted for Spirastrella inconstant protein (Zhu et al., 2008). SDS-PAGE was carried out following the modified method of Laemmli, 1970.

\subsection{Column Chromatography}

\subsubsection{Preparation of Sephadex G-50}

About 2-3 gm of Sephadex G-50 was added to $500 \mathrm{ml}$ distilled water, allowed for $3 \mathrm{hrs}$. Supernatant discarded and column material was treated with $200 \mathrm{ml}$ of $0.1 \mathrm{~N} \mathrm{NaOH}$ and left for $30 \mathrm{~min}$. Supernatant discarded, washed with distilled water until the neutral reaction. Repeated washing with $200 \mathrm{ml}$ of $0.1 \mathrm{~N} \mathrm{HCl}$.

\subsubsection{Packing of Chromatographic Column}

By using Column was packed by first making bed of column with glass wool evenly and then attaching the top of the burette with a rubber tube with pinch cork arrangement. Column fixed to stand in vertical position. Slurry was poured in column without air bubbles and to have even distribution of Sephadex slurry and allowed to settle.

\subsubsection{Pretreatment, Loading and Elution of Column}

Column washed with $10 \mathrm{mM}$ Phosphate buffer with two gradients of saline (50 mM and $150 \mathrm{mM}) p \mathrm{H}-7.4$, till the out flow of buffer shows the same $\mathrm{pH}$. After packing the column the sample was layered on top of Sephadex column when entered the matrix, constant flow of buffer was maintained to collect fractions at 13 drops $/ \mathrm{min} 3.0$ $\mathrm{ml}$, with the fractions up to 75 for each saturation level. Fractionation of proteins using column was done. Each fraction was analyzed for protein concentration, using $\mathrm{A}_{280}$ at Lowry's method, and purified by SDS-PAGE. The high specific activity fractions are pooled and subjected to further purification (Mohankumar and Tamil selvi, 2012).

\subsection{Purification of Proteins}

\subsubsection{Anion Exchange Chromatography (DEAE Sepharose Fast Flow)}

Fraction IV obtained was dialyzed against $10 \mathrm{mM}$ Tris-HCl, $p \mathrm{H} 7.46$ for $5 \mathrm{hrs}$ and injected into a pre equilibrated DEAE Sepharose fast flow column, with Tris $\mathrm{HCl}$ buffer. The column was washed until the baseline returned to 0 . The column was then eluted with increasing concentration of $\mathrm{NaCl}$ prepared in $10 \mathrm{mM}$ Tris $\mathrm{HCl}$ buffer, $\mathrm{pH}$ 7.46 at $4^{\circ} \mathrm{C}$. Aliquots of $5 \mathrm{ml} /$ tube were collected at flow rate of $1.2 \mathrm{ml} / \mathrm{min}$ and absorbance was measured at 280 $\mathrm{nm}$.

\subsubsection{Gel Filtration Chromatography (Sephadex G-50)}

The protein solution that passed through the anion exchange chromatographic column was concentrated by freeze-drying and loaded on to a pre equilibrated Sephadex G-50 column with $10 \mathrm{mM}$ Tris $\mathrm{HCl}$ buffer, $\mathrm{pH}$ 7.46. The flow rate was $0.65 \mathrm{ml} / \mathrm{min}$, and the absorbance was monitored at $280 \mathrm{~nm}$ (Song et al., 2008).

\subsection{Isolation of Lectin from Marine Organism}

Internal organs of Spirastrella inconstans were homogenized with $0.1 \mathrm{M}$ TBS at 1:5 (w/v) ratio (Elmer-Rico, 2005). Homogenate was stirred at $10^{\circ} \mathrm{C}$ for $6 \mathrm{hrs}$ and filtered. The supernatant was centrifuged at $10000 \mathrm{rpm}$ for $10 \mathrm{~min}$ at $10^{\circ} \mathrm{C}$. Extract precipitated at $90 \%$ saturation. The precipitate obtained by centrifugation at $10000 \mathrm{rpm}$ for $10 \mathrm{~min}$ at $10^{\circ} \mathrm{C}$, dissolved in buffer and reprecipitated at $0-60 \%$ saturation with Ammonium sulfate, resulting precipitate was collected by centrifugation, dissolved in TBE and dialysis tubing with a molecular weight cut-off of 12000 at $10^{\circ} \mathrm{C}$.

\subsection{Thin Layer Chromatography}

Silica gel slurry with $0.2 \mathrm{M}$ Sodium acetate buffer was activated at $100-105^{\circ} \mathrm{C}$ for $30 \mathrm{~min}$, samples were spotted and dried. After an hour the solvent along with a cover plate ensures that the atmosphere within the tank was saturated. After equilibrium TLC plate was kept vertically with the spotted area dipped in solvent saturated. Solvent ascends the plate about $12 \mathrm{~cm}$ from the origin. The solvent evaporated up from the plate and the solvent front was marked. The plate was then sprayed with Ninhydrin and allowed to dry at $100^{\circ} \mathrm{C}$ for $10-20 \mathrm{~min}$. $\mathrm{R}_{\mathrm{f}}$ value was calculated.

\subsection{Chemical Screening- TLC}

The crude extract dissolved in dichloromethane was placed on a TLC plate and eluted using mixtures of hexane 
and ethyl acetate in a saturated chromatographic cell. The plate was then sprayed with the following locating agents: (i) vanillin solution ( $1 \%$ vanillin in $50 \%$ phosphoric acid); (ii) ninhydrin solution $(0.4 \%$ of ninhydrin in ethanol); and distilled water $(40 \mathrm{~mL})$ and solution B $(8 \mathrm{gm}$ potassium iodide dissolved in distilled water $(20 \mathrm{~mL})$ and saturated with tartaric acid. Alanine was used in the case of ninhydrin (Li et al., 2006).

\subsection{TLC Autobiography Overlay Assay}

A solvent without culture supernatant was extracted 3 times with $100 \mathrm{ml}$ Ethyl acetate. Crude extract with Ethyl acetate was made up to concentration of $100 \mathrm{mg} \mathrm{ml}^{-1} .2 \mu \mathrm{l}$ solution was submitted to TLC on silica gel plate using Dichloromethane: Ethyl acetate: Methanol (5:5:1) as the mobile phase. UV/Vis absorption was used for detection at $254 \mathrm{~nm}$ and $365 \mathrm{~nm}$. The TLC plates were sterilized by UV lamp for $30 \mathrm{~min}$ before enchased in the base nutrient agar. Covered by nutrient agar $\left(46^{\circ} \mathrm{C}\right)$ containing Staphylococcus aureus. After $10 \mathrm{hrs}$ diffusion at $8^{\circ} \mathrm{C}$, incubated at $37^{\circ} \mathrm{C}$ for $24 \mathrm{hrs}$ and agar was sprayed with $5 \mathrm{mg} \mathrm{ml}^{-1}$ of MMT (Methylthiazole tetrazolium). Inhibitions of zones were observed as clear spots against a purple background and their $\mathrm{R}_{\mathrm{f}}$ values were calculated (Li et al., 2005).

\subsection{SDS-PAGE for Purified Protein}

The Laemmli gel (Lamemli, 1970) with an acrylamide concentration of $5 \%$ for the stacking gel and $12 \%$ for the running gel, and SDS-PAGE with an acrylamide concentration of $4 \%$ for the stacking gel, $10 \%$ for the space gel and $15.5 \%$ for the running gel. Protein bands were detected by Coomassie blue staining method (Stephano et al., 1986). Gelatin Zymography was also carried out.

\section{Results}

\subsection{Enzymatic Analysis of Marine Bacteria and MRSA}

The marine organism (bacteria from different source) was broadly used to check the bioactivity against MRSA, since it was isolated from fisherman wound. Spirastrella inconstans was collected during the period of our sample collection and also it had better activity, so it was used in the work. Compared to other marine organism or marine sponge Spirastrella inconstans was obtained in large number, which made to continue the work further. The isolated marine bacteria includes Bacillus sp., Pseudomonas sp., Staphylococcus sp. and Vibrio sp.

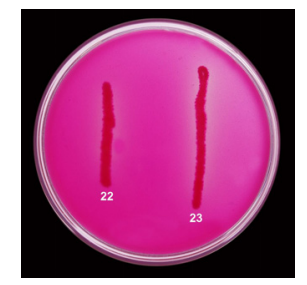

a. Lipase

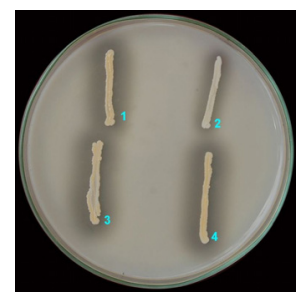

c. Dnase

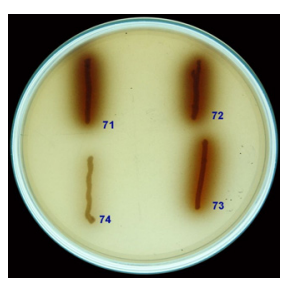

b. Esculinase

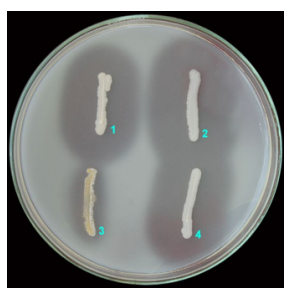

d. Gelatinase

Figure 1. Production of extracellular enzyme showing positive result among marine bacteria

Amount of Lipase was estimated by plate assay method and titration method in which few strains of MRSA showed lipase production. They are negative for Amylase production and positive for DNase and Gelatinase and negative for Alginase production. Variation of Esculin production was observed. The nature of enzymatic activity varies among different strains in case of marine bacteria. The extracellular enzymes produced by plate precipitation test include lipase, amylase, DNase, esculinase, gelatinase and alginase using differential media. The extracellular enzymes were tested against MRSA isolated from fisherman wound, since biosignificance of marine organism may help coastal area people in commercial value. Enzyme, serratia peptidase from the rat fish 
isolate (Serratia sp.) seems to be more effective compared to other isolates.

All the enzymes were studied by assay procedure for detecting best enzyme by molecular level. Lipase showed better result compared to others next to protease. The highest value of lipase by MRSA isolate No. FM 3 using titration method was 55.99 units $/ \mathrm{ml} / \mathrm{min}$. Zymographic study shows that lipase bears activity against MRSA. But compared to that of sponge protein, marine bacterial enzymes were not much more effective. Thus the bioactive compounds from the marine organisms were tested against MD-MRSA.

Among the marine organism screened sponge was selected for the study, which had positive action against pathogens.

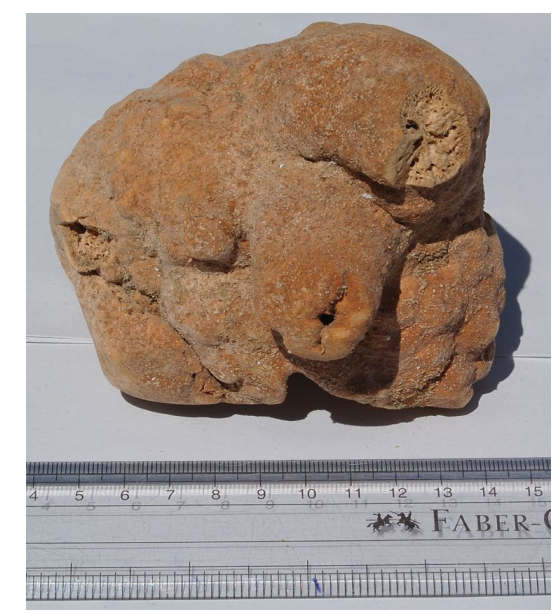

Figure 2. Anti-MRSA activity of Spirastrella inconstans

The Sponge was identified as Spirastrella inconstans by the scientist of ZSI (Zoological survey of india) by its morphological characters.

\subsection{Antimicrobial Activity of Spirastrella inconstans}

Among the solvents of Spirastrella inconstans tested against MRSA chloroform seems to be much effective. The maximum inhibition using Chloroform was about $30 \mathrm{~mm}$ and minimum inhibition was $9 \mathrm{~mm}$ (Table 1). Less bioactivity was observed in case of Acetone. The Chloroform was followed by Dichloromethane, Methanol, Ethanol, Petroleum ether and Acetone (Figure 3).

Acetone had high stimulatory effect on the lipase activity. Tween 80 when used as the principal carbon sources produced maximum lipase. Yeast extract was the best nitrogen source for lipase production. Drop in enzyme activity was directly proportional to the concentration of oleic acid used. Optimal assay temperature for lipase activity was found between 25 and $35^{\circ} \mathrm{C}$. Marine bacteria show drastic increase in its growth from $\mathrm{pH} 14$.

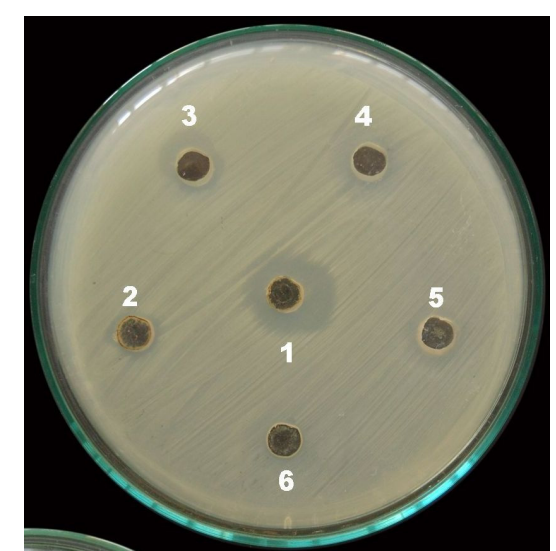

Figure 3. Anti-MRSA activity of Spirastrella inconstans

Key: 1- Chloroform; 2- Dichloromethane; 3- Methanol, 4- Ethanol; 5- Petroleum ether and 6- Acetone 
Table 1. Antimicrobial activity of Spirastrella inconstans extract against MRSA

\begin{tabular}{|c|c|c|c|c|c|c|c|}
\hline \multirow[t]{2}{*}{ S. No } & \multirow{2}{*}{$\begin{array}{c}\text { Strain } \\
\text { No. }\end{array}$} & \multicolumn{6}{|c|}{ Diameter of zone of inhibition } \\
\hline & & Chloroform & $\begin{array}{l}\text { Dichloro } \\
\text { methane }\end{array}$ & Methanol & Ethanol & $\begin{array}{l}\text { Petroleum } \\
\text { ether }\end{array}$ & Acetone \\
\hline 1 & FM 4 & 24 & 16 & 16 & 16 & 10 & - \\
\hline 2 & FM 5 & 11 & - & - & 11 & - & - \\
\hline 3 & FM 6 & 10 & 11 & - & - & - & 11 \\
\hline 4 & FM 20 & 14 & 12 & 14 & 18 & 16 & - \\
\hline 5 & FM 21 & 10 & - & 8 & 10 & - & - \\
\hline 6 & FM 22 & 12 & 12 & 15 & 22 & - & - \\
\hline 7 & FM 23 & 11 & 11 & 10 & 16 & - & - \\
\hline 8 & FM 26 & 14 & 12 & 12 & - & - & - \\
\hline 9 & FM 27 & 10 & - & 11 & 8 & - & - \\
\hline 10 & FM 31 & 12 & 10 & 10 & 12 & - & - \\
\hline 11 & FM 32 & 12 & 11 & 16 & 10 & 15 & - \\
\hline 12 & FM 45 & 14 & 11 & 8 & 9 & - & - \\
\hline 13 & FM 47 & 14 & 9 & 13 & 11 & - & - \\
\hline 14 & FM 48 & 12 & 13 & 12 & 13 & - & - \\
\hline 15 & FM 49 & 20 & 18 & 14 & 18 & 15 & - \\
\hline 16 & FM 50 & 14 & 9 & 19 & 18 & - & - \\
\hline 17 & FM 51 & 14 & 14 & 10 & 11 & - & - \\
\hline 18 & FM 53 & 18 & 16 & 11 & 11 & - & - \\
\hline 19 & FM 54 & 14 & 10 & 11 & 10 & - & - \\
\hline 20 & FM 55 & 14 & 12 & 12 & - & - & - \\
\hline 21 & FM 56 & 13 & - & - & 11 & - & - \\
\hline 22 & FM 58 & 17 & - & - & 13 & - & - \\
\hline 23 & FM 60 & 14 & 18 & 10 & 11 & - & - \\
\hline 24 & FM 61 & 15 & 11 & - & 11 & - & - \\
\hline 25 & FM 62 & 15 & 10 & 14 & 11 & - & - \\
\hline 26 & FM 68 & 12 & 11 & 20 & 10 & - & - \\
\hline 27 & FM 69 & 15 & 10 & 10 & 17 & - & - \\
\hline 28 & FM 70 & 16 & 12 & 11 & 12 & - & - \\
\hline 29 & FM 71 & 15 & 15 & 10 & - & - & - \\
\hline 30 & FM 72 & 30 & 14 & - & 16 & - & - \\
\hline 31 & FM 73 & 12 & - & 11 & 13 & - & 11 \\
\hline 32 & FM 74 & 15 & - & 10 & 15 & 16 & 11 \\
\hline 33 & FM 76 & 13 & 14 & 10 & 15 & - & - \\
\hline 34 & FM 80 & 14 & 12 & 12 & 13 & - & - \\
\hline 35 & FM 81 & 10 & - & 16 & 15 & - & - \\
\hline 36 & FM 82 & 12 & 11 & 16 & 14 & 10 & 11 \\
\hline 37 & FM 83 & 15 & 11 & 10 & 15 & 10 & 12 \\
\hline 38 & FM 84 & 24 & 13 & 16 & 17 & - & 17 \\
\hline 39 & FM 85 & 17 & - & - & 15 & - & - \\
\hline 40 & FM 86 & 12 & - & 13 & 18 & - & - \\
\hline 41 & FM 88 & 23 & 8 & 15 & 18 & 11 & 14 \\
\hline 42 & FM 92 & 14 & 16 & - & 12 & - & - \\
\hline 43 & FM 93 & 11 & - & - & 13 & - & - \\
\hline 44 & FM 95 & 9 & - & - & - & - & - \\
\hline
\end{tabular}

Key: FM- Fisherman wound MRSA strain. 
Acetone had high stimulatory effect on the lipase activity. Tween 80 when used as the principal carbon sources produced maximum lipase. Yeast extract was the best nitrogen source for lipase production. Drop in enzyme activity was directly proportional to the concentration of oleic acid used. Optimal assay temperature for lipase activity was found between 25 and $35^{\circ} \mathrm{C}$. Marine bacteria show drastic increase in its growth from $\mathrm{pH} 14$.

\subsection{Extraction of Protein from Spirastrella Inconstans}

Crude protein obtained from Dialysis was further purified by Column Chromatography by collecting about 75 fractions in $20 \%, 40 \%, 60 \%$ and $80 \%$ saturation level. The fourth fraction of $40 \%$ and $60 \%$ bioactive compounds was indicated by dark color among all fractions obtained. The amounts of protein were estimated by UV-Vis Spectrophotometer.

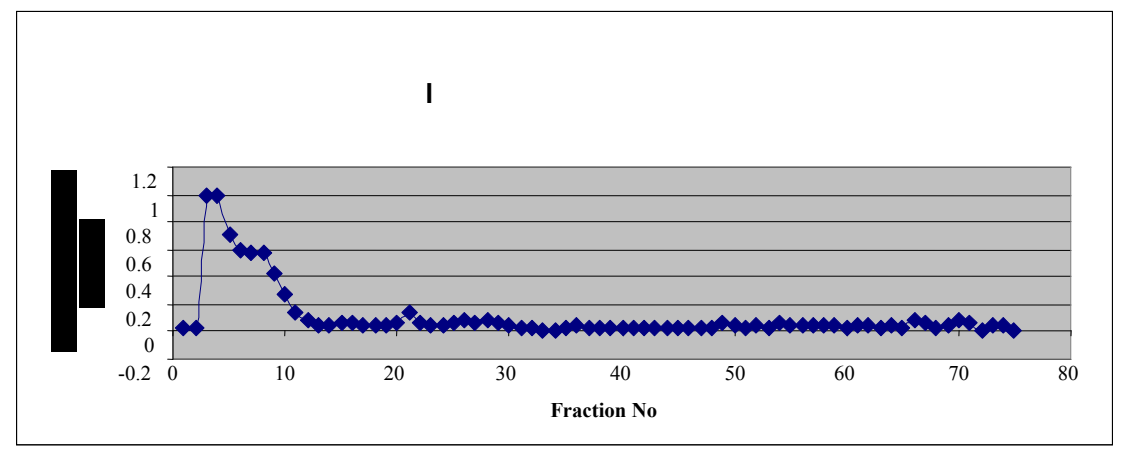

Figure 4. Estimation of Protein content in Spirastrella inconstans at 40\% saturation level

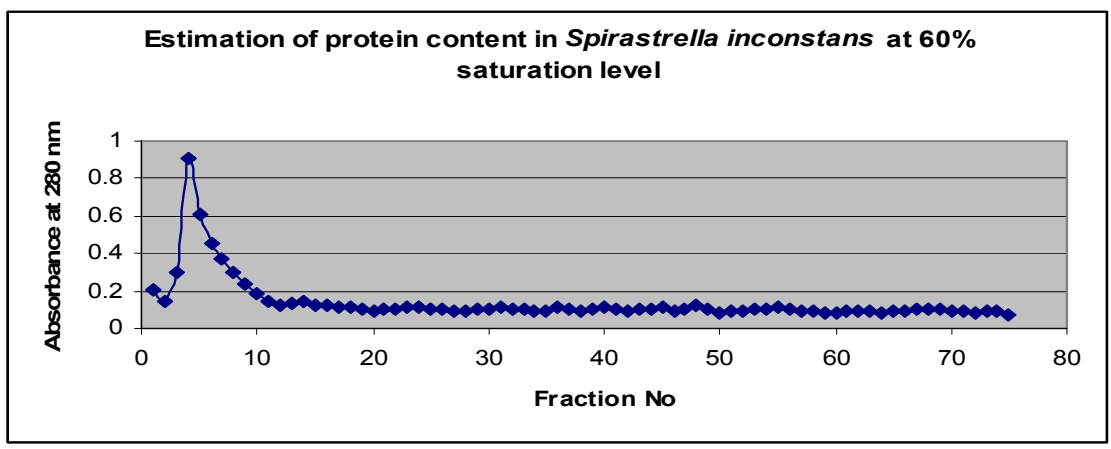

Figure 5. Estimation of protein content in Spirastrella inconstans at 60\% saturation level

If the absorbance value at $280 \mathrm{~nm}$ by using UV-Vis Spectrophotometer is 1 or 0.9 absorbance means it's supposed to be protein. Lowry's method confirms the presence of protein. The fractions bearing the maximum protein content were taken in to account for further characterization, such as fraction no. 3 and $4(40 \%$ saturation), $4(60 \%$ saturation $)$, and $5(80 \%$ saturation $)$ with absorbance value of greater than one.

\subsection{Preliminary Identification of Bioactive Compound from Spirastrella Inconstans}

An autobiography result shows the presence of proteins. TLC showed the spots indicating the presence of amino acid content in that fraction. Based on the measurement of $R_{f}$ value calculated compound would be glutamic acid.

\subsection{SDS-PAGE}

Among 75 fractions collected in each percentage of saturation levels fourth fraction of $40 \%$ and $60 \%$ saturation level showed the protein content, which were analyzed by SDS-PAGE. The bands obtained were compared with the low molecular weight marker, thus indicating that the protein of Spirastrella inconstans extract with 3000 Da from fraction number 4 and 79. Spirastrella inconstans protein posses better activity than the enzymes of marine bacteria against MRSA. 


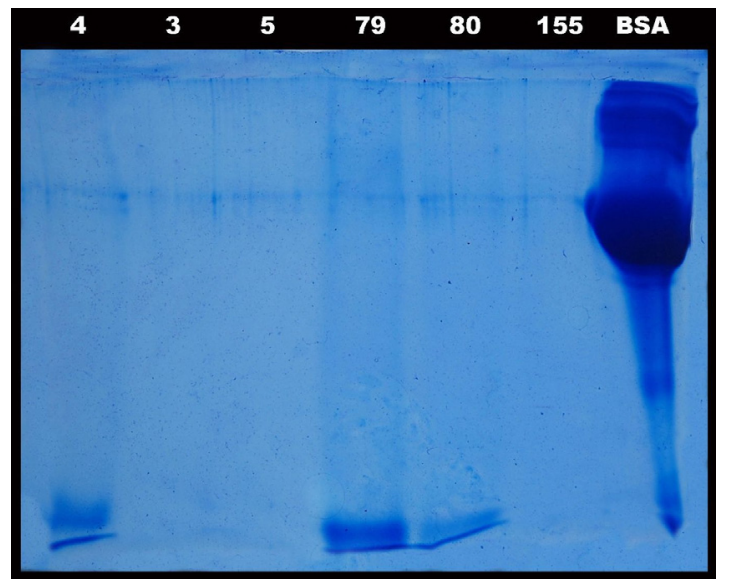

Figure 6. Confirmation of crude protein in Spirastrella inconstans by SDS-PAGE

\section{Discussion}

The invertebrate resource minimum diversity was observed during the post monsoon in March and maximum was found during the summer season in April by Balaji et al. (2007). According to Arti Tyagi et al. (2008), Yeast extract produced maximum enzyme among all organic nitrogen sources studied yielding $5.21 \mathrm{U} / \mathrm{ml}$. Among the inorganic sources, only ammonium nitrate gave the comparable enzyme yield. Alkaline lipases active at $p \mathrm{H}$ above 7.0 have been reported from Staphylococcus sp. Oleic acid supplementation in the production media resulted in repression of lipase synthesis and drop in enzyme activity was directly proportional to the concentration of oleic acid used.

Growth medium containing a high concentration of $\mathrm{NaCl}$ enabled the bacterium to grow at high temperature. Interactions between the effects of temperature and $\mathrm{NaCl}$ concentration on growth of halophilic bacterium have been reported by Werasit Kanlayakrit et al. (2001).

Natural marine waters contain hundreds of bacteria per milliliter, and marine sediments thousands per ml, as shown for Santa Monica Basin and Dana Point samples. But surface waters contain 300 bacteria/ml (30 000/100 $\mathrm{ml}$ ); mid water sample may contain less $(10-100 / \mathrm{ml})$, except near the sewage outfalls. There appear to be no striking differences in bacteria concentrations in sediments from Dana Point, Santa Monica Basin, or near the discharge sites in Santa Monica Bay, but the concentration range is one to two orders of magnitude higher than in water samples of equivalent volume. (ftp://ftp.sccwrp.org/pub/download/PDFs-delete/1975ANNUALREPORT/01_.pdf).

In 1947, Rosenfeld and Zobell had carried out the first detailed study of antibiotic-producing marine bacteria. Since then, there are several reports of antibiotic-producing marine bacteria showing the antagonistic effect against human pathogens, as strains of pathogenic bacteria that recently emerged are unresponsive or multidrug resistant to the already discovered antibiotic that are in use (Asha Devi et al., 2008). Prabhdeep Sidhu et al., (1998) made observation that lipase from most of Pseudomonas sp. Bacillus subtilis 168 and Staphylococcus warneri had been known to be activated by addition of $\mathrm{Ca}^{2+}$. Optimal assay temperature for the lipase activity was found to be between 25 and $35^{\circ} \mathrm{C}$ in case of Staphylococcus warneri.

A total of 82 stains were isolated from water and sediment samples of eight stations. Based on colony morphology, 42 strains were selected, sub-cultured and identified as 12 genera which includes Flavobacterium, Bacillus, Shigella, Klebsiella, Corynebacterium, Pseudomonas, Aeromonas, Vibrio, Streptococcus, Escherichia, Proteus and Salmonella of these Vibrio contributed more (23\%) followed by Pseudomonas (20\%) E. coli (17\%) and Streptococcus (15\%). In the case of pathogenic bacteria of Vibrio and Salmonella species higher pathogenic but less populated bacterial load were recorded from Nicobar island as suggested by Swarnakumar et al. (2008).

Mucus from the coral was good medium for the growth of marine bacteria so the level of the bacterial productivity in the coral mucus is greater than in the surrounding water. It has been hypothesized that marine bacteria associated with invertebrates and vertebrates secrete a number of antibacterial agents that may provide a level of immunity to the corals (Murugan et al., 2007).

Nural Cevahir et al. (2008) noted that gelatinase is protease that is capable of hydrolyzing gelatin, collagen, casein, hemoglobin, and other bioactive peptides. Proteinases are associated with inflammation, and this has 
been shown to contribute to virulence in human and animal models. Gelatinase producing strains have shown to contribute to the virulence of endocarditis in an animal model. It may be advantageous for the enterococci to hydrolyze collagen in subcutaneous tissues during wound infection. According to Nagvenkar (2006) a comparative analysis of microbial communities in different organs (surface, gills, intestinal tract) showed that high diversity noticed in the intestinal tract followed by surface and gill and also revealed the prevalent of gram negative strain in the intestinal tract of mullets. The results of enzyme production indicate that the isolated colonies play an important role in influencing the proteolytic and amylolytic activity.

The effect of organic solvents on enzymes activity, benzene and hexane had stimulatory effect on the lipase activity. The activity of enzymes was stimulated up to $60 \%$ of hexane or benzene in reaction mixture. The enzyme activity was slightly stimulated up to $30 \%$ in presence of acetone. Dimethyl sulphoxide and ethylene glycol had almost no effect, while ethanol, methanol and propanol inhibited the enzyme activity. The effect of organic solvents might be attributed to the water content in reaction mix. Water plays a significant role in the activity of the enzymes. The inhibition of lipase in presence of ethanol, methanol while stimulation in water immiscible solvents confirms that polar water miscible solvents are more destabilizing than the water immiscible solvents (Nawani et al., 2006).

By bioautography, the extract of the sponge collected in TAMA showed a significant inhibition zone in the less polar area of the TLC plate. Although TLC and bioautography analyses of the crude extracts revealed a difference in the composition of less polar compounds those that inhibit the growth of the marine bacterium in Epifanio et al. (2005) report. Li Kam Wah et al. (2006) made observation in his study by using different crude extracts which were chemically screened using TLC. Three different locating reagents, namely vanillin, ninhydrin, and Dragendorff were used to evaluate the abundance of secondary metabolites in the crude extracts. Vanillin was used to detect the presence of organic compounds such as terpenes, alkaloids, peptides, and sterols; ninhydrin to detect the presence of amino acids and peptides and Dragendorff to detect the presence of alkaloids. But in the case of present study amino acid shows positive result.

Boobathy et al. (2009) obtained the crude protein content of $1.62 \mathrm{mg} / \mathrm{mL}$ in methanolic crude extract and 1.43 $\mathrm{mg} / \mathrm{mL}$ in the aqueous extract of marine sponge Callyspongia diffusa. The SDS-PAGE on gel, crude protein toxins yielded 6 bands in the chloroform extract and 5 bands in the aqueous extract of S. fibulatus, ranging from 14.4 to $116 \mathrm{kDa}$ molecular weight with 5 well-defined bands of 28.5, 35.4, 45.0, 59.5, 72.3 kDa in both the extracts. The presence of 3 protein bands viz, 19.5, 39.0 and $66.2 \mathrm{kDa}$ already reported in C. diffusa.

\section{Conclusion}

The world's oceans will play an important part in the future control of the global infectious disease burden. The purified enzyme from the sponge, Spirastrella inconstans had better antimicrobial activity against (MDR-MRSA) multidrug resistant- Methicillin Resistant Staphylococcus aureus from fisherman Wound. Thus the enzyme protein from $S$. inconstans can be used for producing bioactive compound compared to that of other marine organism obtained from different marine source. Future work of structural elucidation of protein molecules may solve the problem of wound infection in better way.

\section{References}

Amador, M. L., Jimeno, J., Paz-Ares, L., Cortes-Funes, H., \& Hdalgo, M. (2003). Progress in development and acquisition of anticancer agents from marine sources. Annals of Oncology, 14, 1607-1615. http://dx.doi.org/10.1093/annonc/mdg443

Anshu, G., Rajni Singh, S., Khare, K., \& Gupta, M. N. (2002). Extracellular alkaline lipase from Enterobacter aerogens. Indian Journal of Microbiology, 42, 263-265.

Arti, T., Arti, K., \& Padma, S. (2008). Incidence of Methicillin Resistance Staphylococcus aureus (MRSA) in Pus Samples at a Tertiary Care Hospital, AIIMS, New Delhi. Journal, Indian Academy of Clinical Medicine, 9(1), 33-35.

Asha Devi, N. K., Balakrishnan, K., Gopal, R., \& Padmavathy, S. (2008). Bacillus clausii MB9 from the east coast regions of India: Isolation, biochemical characterization and antimicrobial potentials. Current Science, 95(5), 627-635.

Balaji, K., Thirumaran, G., Arumugan, R., Kumaraguruvasagam, K. P., \& Anatharaman, P. (2007). Marine Ornamental Invertebrate Resources of Paragipettai Coastal Waters (South East Coast of India). Journal of Fisheries and Aquatic Sciences, 2(5), 328-336. http://dx.doi.org/10.3923/jfas.2007.328.336

Boobathy, S., Ajith Kumar, T. T., \& Kathiresan, K. (2009). Isolation of symbiotic bacteria and bioactive proteins from the marine sponge, Callyspongia diffusa. Indian Journal of Biotechnology, 8, 272-275. 
Davis, B. R., \& Ewing, W. H. (1964). Lipolytic, Pectolytic, and Alginolytic activities of Enterobacteriaceae. Journal of Bacteriology, 88(1), 16-19.

Dovi, K., Yoel, K., Eugene, R., Micha, I.n, Ilan, I., \& Yossi, L. (2001). Antimicrobial activity of the reef sponge Amphimedon viridis from the Red sea: evidence for selective toxicity. Aquatic microbial Ecology, 24, 9-16. http://dx.doi.org/10.3354/ame024009

Elmer-Rico, E. M., \& Florina, E. M. (2005). Biological properties of Lectin from Sea Cucumber (Holothuria scabra Jaegar). Journal of Biological Sciences, 5(4), 472-477. http://dx.doi.org/10.3923/jbs.2005.472.477

Epifanio, R. A., Leandro S., Pinheiro, \& Natalia C. Alves. (2005). Polyketides from the Marine Sponge Plakortis $\begin{array}{llllll}\text { angulospiculatus. } & \text { J. Braz. } & \text { Chem. } & \text { Soc., } & \text { 16(6B), } & \text { 1367-1371. }\end{array}$ http://dx.doi.org/10.1590/S0103-50532005000800010

Gerald, J. B., \& Green, Gerardo. (1981). Toxicity in sponges and holothurians A geographic pattern. Science, 185, 951-953.

Gisela, K., \& Karl-Erlich, J. (1987). Specific and Sensitive plate Assay for Bacterial Lipases. Applied and Environmental Microbiology, 53(1), 211-213.

Jan, R., \& Staffen, N. (1992). In Vivo processing of Staphylococcus aureus Lipase. Journal of Bacteriology, 174(6), 1844-1847.

Lamemli, U. K. (1970). Cleavage of structural proteins during the assembly of the head of bacteriophage T4. Nature, 227(5259), 680-688. http://dx.doi.org/10.1038/227680a0

Li Kam Wah, H., Jhaumeer-Laulloo, S., Choong Kwet Yive, R., Bonnard, I., Banaigs, B., \& Marie, D. (2006). Biological and Chemical Study of Some Soft Coral and Sponges Collected in Mauritian Waters. Western Indian Ocean J. Mar. Sci, 5(2), 115-121.

Limna Mol, V. P., Raveendran, T. V., Abhilash, K. R., \& Parameswaran, P. S. (2010). Inhibitory effect of Indian Sponge extracts on bacterial strains and larval settlement of the barnacle. Balanus amphitrite. Int. Biodeterior. Biodegrad, 64(6), 506-510. http://dx.doi.org/10.1016/j.ibiod.2010.06.003

Longshaw, C. M., Angela M., Farrell, John D. Wright, \& Keith T. Holland. (2000). Identification of a second lipase gene, geneD, in Staphylococcus epidermidis: comparison of sequence with those of other Staphylococcal lipases. Microbiology, 146, 1419-1427.

Lowry, H. O., Nira Rosbrough, A., Lewis, Farr, \& Rose J. Randall. (1951). Protein measurement with the Folin Phenol reagent. The Journal of Biological chemistry, 265-275.

Mohankumar, A., \& Tamil selvi, S. (2012). Bioactive compounds from Spirastrella inconstans against wound infection. Journal of asian scientific research, 2(1), 31-39.

Murugan, K., Aziz, A., \& Zaleha, K. (2007). Isolation, Characterization and Identification of Bacteria associated with Mucus of Acropora cervicornis Coral from Bidong Island, Terengganu, Malaysia. Malaysian Journal of Science, 26(2), 27-39.

Nagvenkar, G. S., Nagvenkar, S. S., Rivonker, C. U., \& Sangodkar, U. M. X. (2006). Microbial diversity and enzyme production in mullet Mugil cephalus L. (Pisces) along Goa, west coast of India. Indian Journal of Marine science, 35(1), 36-42.

Neerupama, N., Rajvinder, S., \& Jagdeep, K. (2006). Immobilization and stability studies of a lipase from thermopilic Bacillus sp: The effect of process parameters on immobilization of enzyme. Electronic Journal of Biotechnology, 9(5), 559-565.

Nural, C., Melek, D., Ilknur, K., Melahat, G., \& Soner, T. (2008). Evaluation of biofilm production, gelatinase activity and mannose-resistant hemagglutination in Acinetobacter baumannii strains. J Microbiol Immunol Infec., 41, 513-518.

Prabhdeep, S., Rohit, S., Soni, S. K., \& Gupta, J. K. (1998). Effect of Cultural Conditions on Extracellular Alkaline Lipase Production by Bacillus sp. RS-12 and its Characterization. Indian Journal of Microbiology, $38,9-14$.

Ravichandran, S., Kathiresan, K., \& Hemalatha, B. (2007). Anti-malarials from marine sponges. Biotechnology and Molecular Biology Review, 2(2), 33-38.

Satheeshkumar, P., Anisa, B. K., \& Senthilkumar, D. (2010). Marine Organisms as Potential Supply for Drug Finding- A Review Study. Middle-East Journal of Scientific Research, 5(6), 514-519. 
Schroder, H. C., Hiroshi, U., Anatoli, K., et al. (2003). Emergence and Disappearance of a Immune Molecule and Antimicrobial Lectin, in Basal Metazoa. The Journal of Biological Chemistry, 278(35), 32810-32817. http://dx.doi.org/10.1074/jbc.M304116200

Song, L. Y., Ren, S. F., Yu, R. M., Yan, C. Y., Li, T. F., \& Zhao, Y. (2008). Purification, Characterization and in vitro anti-tumor activity of proteins from Arca subcrenata Lischke. Mar. Drugs, 6, 418-430. http://dx.doi.org/10.3390/md6030418

Stephano, J. L., Gould, M., \& Rojas-Galicia, L. (1986). Advantages of picrate fixation for staining polyproteins in polyacrylamide gels. Anal. Biochem, 152, 308-313. http://dx.doi.org/10.1016/0003-2697(86)90414-8

Swarnakumar, N. S., Maloy Kumar, S., Sivakumara, K., \& Thangaradjou, T. (2008). Assessment of microbial pollution in the coastal environs of the Little Andaman island, India. Indian journal of Marine Sciences, 37(2), 146-152.

Tahere, B., Seyed, A. H., Vahid, Y., Morteza, A., \& Ali, F. (2008). Growth, Survival and Gut Microbial Load of Rainbow Trout (Onchorhynchus mykiss) Fry Given Diet Supplemented with Probiotic during the Two Months of First Feeding. Turkish Journal of Fisheries and Aquatic Sciences, 8, 43-48.

Tonima, K., Celina, R., \& Chandrakant, G. N. (2008). Marine-derived fungi as a source of proteases. Indian journal of Marine Sciences, 37(3), 326-328.

Werasit, K., Takahiro, I., Somporn, T., Mangkorn, R., \& Sarote, S. (2001). Isolation and Characterization of Extracellular Halophilic Ribonuclease from Halotolerant Pseudomonas species. Kasetsart J. (Nat. Sci), 35, 179-187.

Zakaria, Z. A., Somchit, M. N., Sulaiman, M. R., \& Mat Jais, A. M. (2004). Preliminary Investigation on the Antinociceptive properties of Harun (Channa striatus) Fillet Extracted with Various Solvent Systems. Pakistan Journal of Biological Sciences, 7(10), 1706-1710. http://dx.doi.org/10.3923/pjbs.2004.1706.1710

Zheng, L., Han, X. T., Chen, H. M., Lin W., \& Yan, X. J. (2005). Marine bacteria associated with marine microorganisms: the potential antimicrobial resources. Annals of Microbiology, 55(2), 119-124.

Zhu, B. W., Sun, L. L. M., Li, D. M., Murata, Y., Yu, L., \& Zhang, L. (2008). Purification and Characterization of a Cathepsin L-Like Enzyme from the body wall of the Sea Cucumber Stichopus japonicus. Biosci. Biotechnol. Biochem, 72(6), 1430-1437. http://dx.doi.org/10.1271/bbb.70741 